\title{
Study on Possibility of Cleaner Production Application at Small Scale Bakery Industry in Pekalongan Indonesia
}

\author{
Tajuddin Bantacut* \\ Siti Kurmeiyanti Zulaikha \\ Department of Agroindustrial Technology, Bogor Agricultural University - Indonesia
}

\begin{abstract}
This study analyzed the opportunities for implementing a cleaner production of small bread industries. The research begun with identification of the process stages, problems and opportunities for the application of cleaner production as well as an analysis of alternative feasibility of environmental, technical and financial aspects. The study found a variety of problems such as no special fermentation chambers, no determination of fermentation time, scattered flour, smoking workers, spilt dough, inappropriate placing goods, and the use of lights during the day, untreated eggshells, leftover bread and off-grade bread, the liquid waste from the washing process goes into the water body, unsold bread, and does not have a halal certificate. The recommended alternatives are making space and determining fermentation time, Good Manufacturing Practices, lighting redesign during the day, eggshells process into fertilizer, the remaining slices of bread and off-grade bread are processed into bread crumb flour, four stages of washing, submitting halal certificates, and bread waste flour as animal feeds. The implementation of cleaner production can: (i) increase bread production of 21.19 to 21.80 ton/month, (ii) reduce washing water from 4,000 to 3,600 liters/month, (iii) cut electricity from 1,613 to 1,593 $\mathrm{kWh} /$ month, (iv) improve treated solid waste from 3.27 to 3.43 tons/month, and (v) increased sales of fresh bread to $34,996 \mathrm{packs} /$ month and sweet bread 14,560 packs/month. The total profit that can be obtained by applying cleaner production is $\mathrm{Rp} 21,324,000$ per month.
\end{abstract}

Keywords: cleaner production, feasibility analysis, small bread industry

DOI: $10.7176 / \mathrm{CPER} / 59-01$

\section{Introduction}

The cleaner production is an effort to carry out an integrated environmental strategy on aspects of processes, products, services to improve efficiency, and reduce risks of humans and the environment (UNEP 1990). It is done by reducing energy consumption and raw materials usage that are safer from the environment and health (Hens et al. 2017). Application of the cleaner production is an important element of environmental management because it can reduce the amount of emissions and waste disposed of in the air, land and water (Tan et al. 2016). It has two advantages that protect the environment and workers as well as lead to increase corporate profits (Fore and Mbohwa 2010). Increasing efficiency, reducing costs, meeting market requirements, increasing environmental compliance, and building public image of companies are some potential benefits (JICA 2002; Abou-Elela 2002).

The cleaner production has been carried out in the fields of both food and non-food industries. Many researches related to its application to the non-food sector among others are furniture industries (Aguilar et al. 2017), textile industries (Tan et al. 2016), and the foundry industries (Fore and Mbohwa 2010). Application for the food industries among others are slaughterhouses (Hafiz et al. 2016), fruit juice drinks (Rahim and Raman 2015), seafood (Dan et al. 2003), Kimchi (Yi et al. 2001). Research on the cleaner production of the food industry continued to be elaborated because the wastes contain high organic materials and nutrients that need to be utilized or treated (Abou-Elela et al. 2008).

Small industries need to carry out cleaner production as a first effort to protect the environment. These industries produce less wastes than large industries, but due to limited technology and the trained workers, and lack of space, they are less in control of waste (Ramjeawon 2004). The biggest pollution in Asian countries is caused by small and medium industrial activities (UNIDO 2009). They have lack efficiency in energy usages and contribute greatly to regional pollution producers (Visvanathan and Kumar 1999).

Small breads industry wastes greatly contribute to environmental quality in Mymensingh Bangladesh (Rahman et al. 2014). This shows the need to pay attention to the existence of small industries because their locations are very close to residential areas so that the environmental impact will disturb the surrounding community. One effort that can be done is applying cleaner production, including in the small bread industry. Research related to the implementation of cleaner production of small industries will help improve their production practice and environmental management.

Multy Bakery is one of the small industries that produce bread in Pekalongan district of Indonesia. This industry produces flat bread and sweet bread. The waste produced includes liquid waste from washing and solid waste as a byproduct of production. This study examined the opportunities for applying cleaner production of the Multy Bakery to find out the amount of waste produced and production handling problems to offer alternative 
process improvements to increase profits.

The purpose of this research was to examine the opportunities for applying cleaner production of small bread industries through identifying production processes and problems, and analyzing the feasibility of alternative solutions. The stages carried out begining with the identification of the flow of the bread making process and energy needs. Efforts to implement the cleaner production cover weighing materials to managing unsold bread returns. Returned breads from store to industry is considered to be wastes. Waste management is carried out by reducing or utilizing wastes so that it can produce various kinds of alternative products. The next stage is the calculation of the feasibility of environmental, technical and financial aspects by calculating the pay back period.

\section{Method}

\subsection{Location and Time}

This study was conducted during April-May 2018 at the Multy Bakery Small Industry, Pekalongan Barat, Pekalongan City, Central Java Province.

\subsection{Type and Source of Data}

Primary and secondary data were used. The primary data was in the form of a flow chart of the bread making process, energy consumption, and the determination of cleaner production alternatives. Data related to energy needs were obtained based on direct observation of tools and machines as well as the results of interviews for workers and business actors about working time of the tool. Determination of cleaner production alternatives was obtained from interviews for business owners and with similar small industries in Bogor area (West Java) and animal feed factories. Secondary data was obtained from business actors to include amount of production and the number of unsold products, and data for financial analysis was obtained from earlier research, books, and journals.

\subsection{Research Stages}

Figure 1 shows stages of the research.

2.3.1. Identification of General Performance of the Company

This stage was carried out to find out the general condition of the company starting from history of the company's establishment, number of workers, production capacity, and company management. Data obtained from interviews and direct observations. Interviews were conducted with owners and workers in the production section.

2.3.2. Identification of Production Process

This stage was to make a flow diagram of the bread production process and energy needs. The bread making flow chart is equipped with inputs and outputs of each process, identifying sources of wastes, energy and water consumption (Aguilar et al. 2017). Energy requirements were calculated based on operational time of the tool and machine.

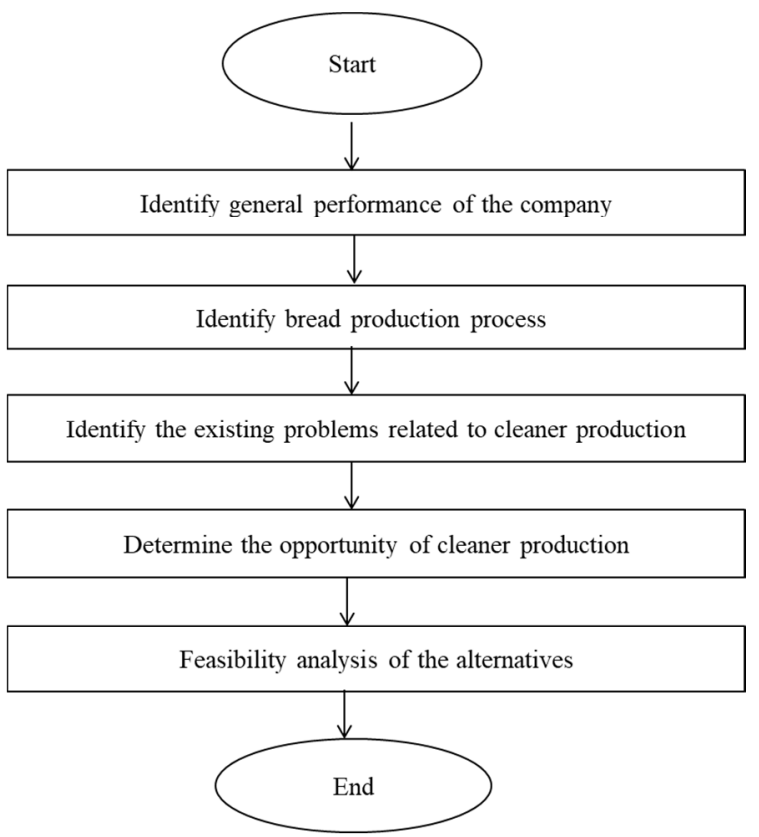

Figure 1. The research flows 


\subsubsection{Identification of Multy Bakery Existing Problems}

This stage was to identify problems exist in Multy Bakery including raw materials used and waste generation in each process. Identification followed process flow charts and energy requirements. Data was gathered by interviewing owners and workers, and conducting direct checks.

2.3.4. Identification of Cleaner Production alternatives

Alternatives of the cleaner production were traced to literature studies by collecting and analyzing secondary data. The data was obtained from journals, books, and other literatures. The alternatives to applying cleaner production of small and medium industries are as follows (Shamsudin et al. 2011):

a. Reduction of energy consumption: this can be done through the efficient use of electricity and the heating and cool process improvement. The efficiency of the heating and cooling process can be done by reducing processing time, reducing/increasing temperatures, recovering energy, using renewable energy, using the right materials, and reducing material losses.

b. Material: the use of good and proper materials is one alternatives in cleaner production. This can be done by preventing material loss, optimizing the use of materials, and using materials that have a smaller impact on the environment.

c. Risk Management: this can be done by minimizing or reducing the risk of accidents and reducing severe consequences such as worker injury, loss of resources, and material loss or damage.

A cleaner production management in small industries can be done through several alternatives such as product modification, input substitution with the use of raw materials that pollute the environment less, technology modification by increasing process automation, good house-keeping with maintenance to avoid waste and emissions, and recycling with turn it into more useful material (Berkel 1999). The alternative preparation of the clean production process are to implement reduce, reuse, and recycle at each stage of the process of the material to the final process (Indrasti and Fauzi 2009).

2.3.5. Feasibility Analysis of the Cleaner Production Alternatives

Analysis for each alternative was carried out on environmental, financial and technical aspects. The environmental feasibility was analyzed by taking into account the impact on each alternative, namely reducing waste in the production process and not creating new waste. Financial feasibility was done by calculating the cost benefits and the payback period (Dan et al. 2003). Alternative with a relatively short payback period should be chosen (Abou-Elela 2002).

The technical feasibility of cleaner production alternatives includes process criteria, materials, equipment, and labor (Indrasti and Fauzi 2009). Process criteria include the suitability of procedures and production with conditions in the industry and process efficiency. Material criteria consist of available equipment capacity, efficiency in the use of raw materials, as well as maintaining product quality. The criteria for equipment are conformity with the availability of places and engine maintenance. The criteria of labor are a safe system for workers and the availability of human resources. This analysis is needed to determine the suitability of selected technologies and the availability of resources in small and medium industry.

\section{Result and Discussion}

\subsection{Bread Production Proces}

3.1.1. Flat Bread Production Process

The ingredients of making flat bread are flour, water, salt, sugar, milk, butter, emulsifiers, yeast and bread improvers. The process consists of weighing raw materials, mixing dough, crunching dough, weighing breadsized dough, rounding, molding, panning, fermentation, roasting, de-panning, cooling, slicing, and packaging (Figure 2) 


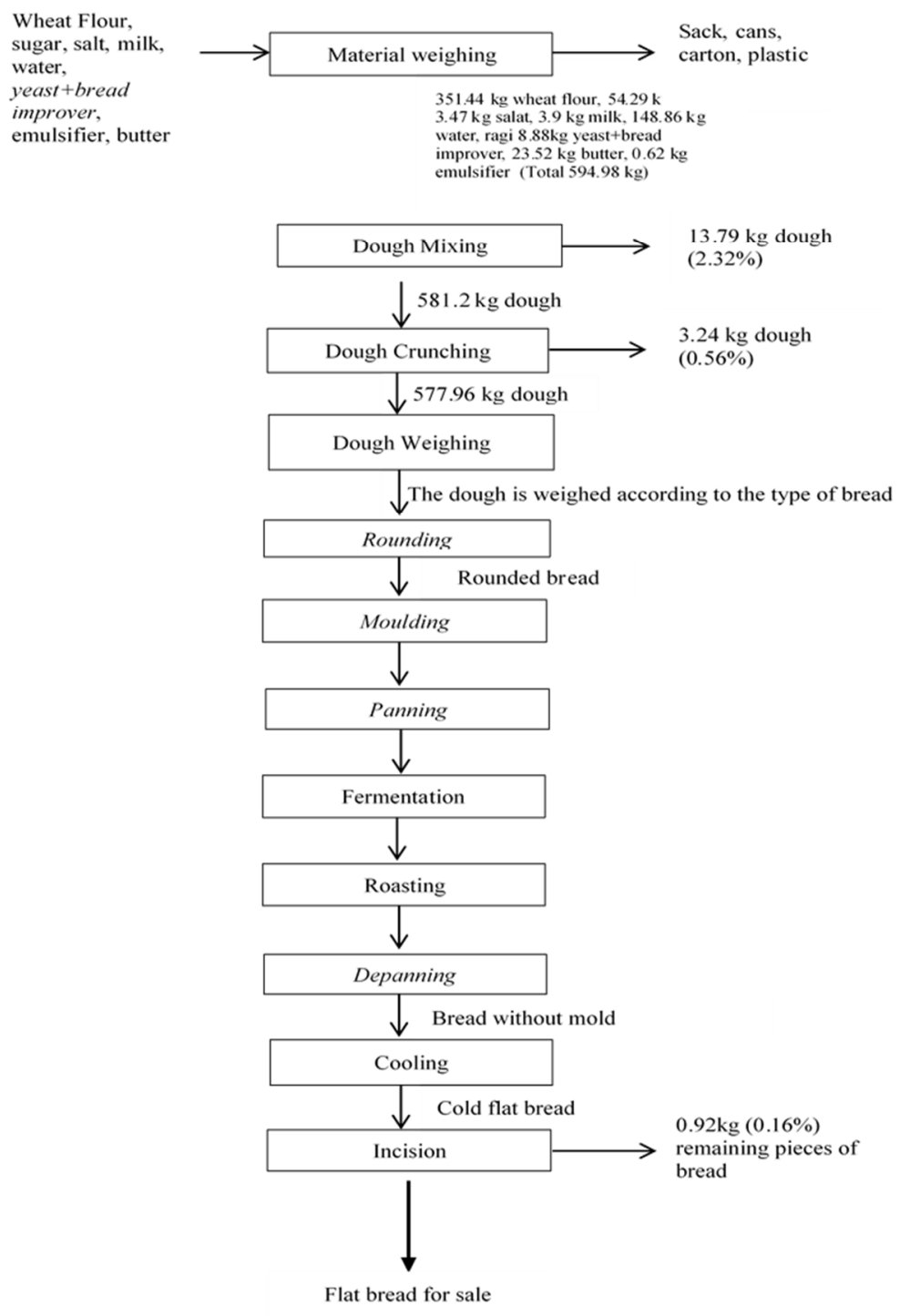

Figure 2. Flowchart of flat bread making process

The dough is adjusted to the type of bread to be produced. Each type of bread has a different weight of dough, this study used the production process of flat bread with a weight of 200 grams of dough. Based on the flow diagram of the process of making flat bread per day it was found that there was a loss of ingredients in several processes (Table 2).

\begin{tabular}{lc}
\multicolumn{2}{l}{ Table 1. Dough loss during flat bread making process } \\
\hline Process & Dough loss $(\mathrm{kg})$ \\
\hline Mixing & 13.79 \\
Crunching & 3.24 \\
Moulding & 0.69 \\
Total & 17.72 \\
\hline
\end{tabular}

The loss of material every day can be used to make flat bread again. The most sold flat bread is afarel type.This bread making requires 300 grams of dough per pack. If the missing mixture were processed into afarel bread will produce 59 packs. The selling price of afarel bread is Rp. 7,000/pack so that the more income that can be obtained is Rp 413,000.

3.1.2. Sweet Bread Production Process

The ingredients used in making sweet bread are wheat flour, sugar, eggs, water, milk, butter, emulsifiers, salt, bread yeast, bread improvers and bread filling ingredients. Sweet bread production process begins with weighing of ingredients, breadline processes, panning, fermentation, roasting, de-panning, cooling, and packaging (Figure 3).

The process of the bread lines to include flaking the dough, filling the bread, and cutting the bread dough. Filling the bread is done, among others, with liquid chocolate jam. The amount of chocolate added to each piece 
of bread is an average of 3 gram. The percentage of material loss in this process is $0.98 \%$. Each type of sweet bread has a difference weight of the dough (Table 3 ).

Table 2. Sweet bread dough

\begin{tabular}{lccc}
\hline Type of bread & $\begin{array}{c}\text { Weight of bread peace } \\
\text { (gram) }\end{array}$ & $\begin{array}{c}\text { Number of breads } \\
\text { peace }\end{array}$ & $\begin{array}{c}\text { Total weight of dough } \\
\text { (gram) }\end{array}$ \\
\hline Combined bread & 25 & 8 & 200 \\
Chocolate bales bread & 28 & 6 & 168 \\
Fantastic chocolate & 25 & 10 & 250 \\
Striped box & 28 & 9 & 252 \\
Mocca pack & 23 & 8 & 184 \\
Sesame chocolate & 25 & 4 & 100 \\
Four flavors & 34.5 & 4 & 138 \\
\hline
\end{tabular}

Based on the flow of the sweet bread making process, total loss of dough occurs to several stages of the process. Dough loss causes losses for this small industry (Table 4). The total loss of the dough can be reused to make sweet bread. The best-selling sweet bread is chocolate bale bread. The dough needed for making brown chocolate bread is 168 grams/pack. If the missing mixture were processed into brown bales, it will produce 32 packs. The addition of revenue is Rp 224,000 / day with the selling price of bread bale being Rp 6,000/pack.

Table 4. Loss of sweet bread dough per day at Multy Bakery
\begin{tabular}{|l|c|}
\hline Process & Dough loss $(\mathrm{kg})$ \\
\hline Mixing & 3.10 \\
\hline Breadlines & 2.39 \\
\hline Total & 5.48 \\
\hline
\end{tabular}

\subsubsection{Energy Use in Making Flat and Sweet Breads}

Energy in the process of making flat and sweet breads is used to run the machines. Energy sources come from public electricity networks and LPG gas. Gas is needed for roasting process. The amount of LPG needed every day is 2 tubes, equal to $1.388 \mathrm{MJ} / \mathrm{kg}$ of dough. Energy consumption is also for non-production processes. The energy in non-production processes for lighting a room. The electricity used is converted in units of $\mathrm{MJ} / \mathrm{kg}$ dough. Table 5 summarizes the daily energy requirements for the production of bread and sweet bread. 


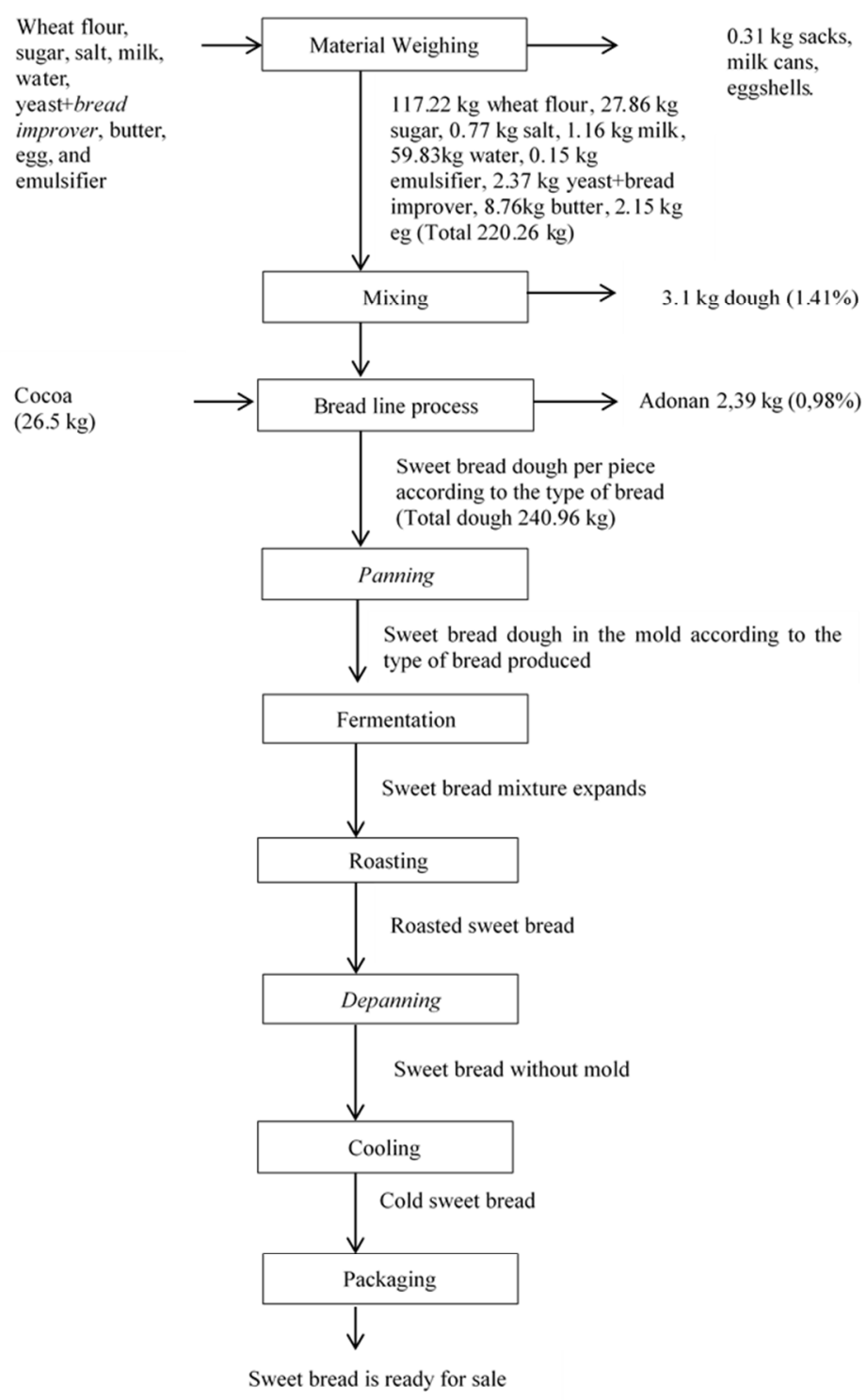

Figure 3. Flowchart of sweet bread making process

Table 3. Electrical energy consumption for flat and sweet bread making

\begin{tabular}{|l|r|r|c|}
\hline \multirow{2}{*}{ Process } & \multicolumn{3}{|c|}{ Electrical energy/day } \\
\cline { 2 - 4 } & $\mathrm{kWh}$ & $\mathrm{MJ}$ & $\mathrm{MJ} / \mathrm{kg}$ dough \\
\hline Mixing & 29.6 & 106.6 & 0.131 \\
\hline Crunching & 12.1 & 43.6 & 0.073 \\
\hline Moulding & 4.2 & 14.9 & 0.025 \\
\hline Roasting & 2.7 & 9.5 & 0.012 \\
\hline Slicing & 0.7 & 2.6 & 0.004 \\
\hline Breadline & 10.5 & 37.9 & 0.172 \\
\hline Non-process & 2.3 & 8.4 & 0.011 \\
\hline Total & 62.1 & 223.5 & 0.428 \\
\hline
\end{tabular}

\subsection{The Problems}

\subsubsection{Waste Generation and Causes}

The bread production processes forms several solid and liquid wastes. Solid wastes are eggshells, the rest of the bread dough attached to the tool, bread that does not pass selection, the remaining slices of bread, and unsold breads. Eggshells are immediately thrown into the environment. The rest of the bread dough attached to the appliance is cleaned every Saturday, then thrown away. Bread that does not pass the selection is immediately discarded along with unsold bread. The bread sales system is done by entrusting to shops. The unsold bread 
made is returned a week after the bread has been deposited. The returned unsold breads are sold to fish farmers. However, in the past few months fish farmers have not needed the bread so that unsold bread has piled up to dozens of sacks. Liquid waste is produced from the washing of the appliance which is carried out every Saturday mixed with flowing water into the body of water.

3.2.2. Problems at Production Activities

Identified problems are seen from several aspects such as raw materials, management, technology, products, and waste. The problems that occur to Multy Bakery can be seen in Figure 4.

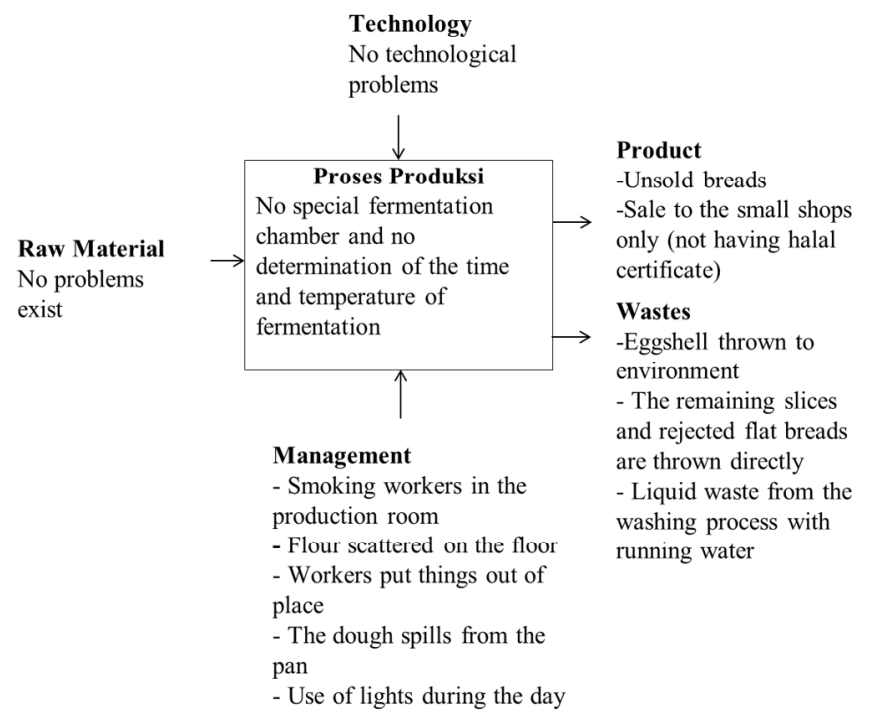

Figure 4. Identified problems at Multy Bakery

\subsection{Cleaner Production Alternatives}

Alternatives of cleaner production are proposed based on the identified problems. Efforts to carry out cleaner production need to be done to solve these problems. The options offered include waste reduction, waste treatment, increased efficiency and overall improvement (Figure 5).

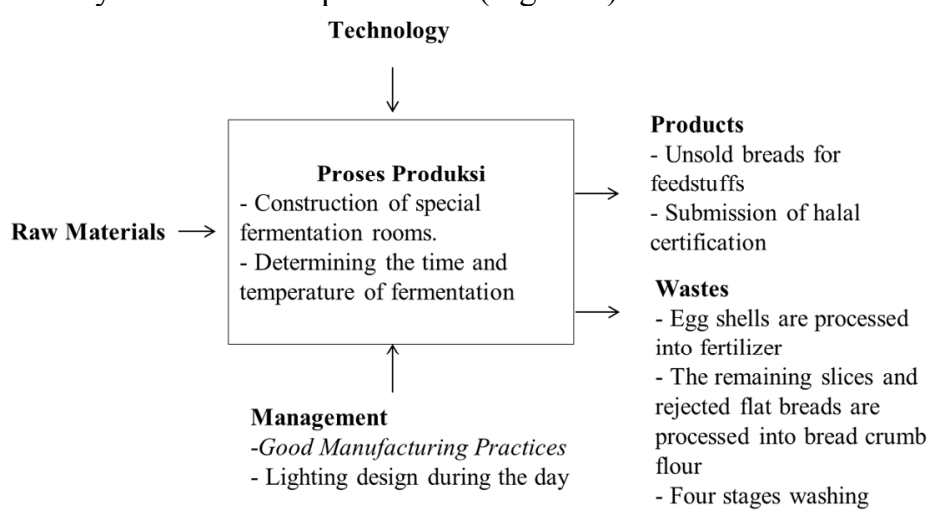

Figure 5. Identification of cleaner production alternative at Multy Bakery

3.3.1. Making Special Fermentation Chamber and Determining Fermentation Times

The fermentation process of Multy Bakery does not have a special place and there is no control of time, temperature, or RH of dough. Fermentation should be done in a special room to be free from contamination. Bread making is basically determined by the fermentation phase because carbon dioxide is related to yeast activity and dough formation (Bajd and Sersa 2011). According to Mudjajanto and Yuliati (2013), bread is allowed to expand on a temperature of $35^{\circ} \mathrm{C}$ and $75 \% \mathrm{RH}$. The fermentation time for bread is done for 60 minutes (Suryatna 2015).

Fermentation rooms should be designed next to the oven because these two processes are sequential and to minimize the workers and materials movements. The fermentation room is equipped with a temperature and humidity measuring device so that it can control the fermentation process properly. Temperature control is carried out by providing indoor LED lights, especially during the rainy season.

3.3.2. Good Manufacturing Practice

Good Manufacturing Practice (GMP) is a guideline on requirements that must be met by producers to produce products that are safe for consumption, having good quality in accordance with consumer demands (Anggraini 
and Yudhastuti 2014). GMP maintains the quality of health and safety of workers through improving the quality of products (Rocha et al. 2009). Training is a key element for increasing awareness, competence, and knowledge related to safety issues (Vos et al. 2018). The introduction to GMP related into production equipment has a positive impact on the development of SMEs (Nugroho et al. 2015).

Application of GMP is expected to increase competitiveness of Multy Bakery with similar industries. GMP can reduce some of the possibilities of product contamination. It will reduce the amount of waste formed because of spilled flour that cause slipping due to slippery floors. In addition, the behavior of workers such as smoking and putting things that are not in place can be reduced. Workers are expected to concentrate on work so that things like pan that fall due to worker negligence can be reduced. This is to reduce losses for the company. Application of SOP is also needed as a preventive measure so that workers are more careful with working.

3.3.3. Daylight Energy Savings

The lighting energy savings during the day at Multy Bakery have not been done. Lights for lighting in the production process keep on for 24 hours. Lighting control is needed because not all facilities require lighting during working hours (Rodriguez 2017). Electricity saving can be done by maximizing light from direct sunlight. Changing a tiled roof of a tinkle solar-tuff can reduce the use of lighting lamps during the day. The use of solar energy can reduce lighting electrical loads (TERI 2016).

3.3.3. Processing Eggshells into Fertilizers

The eggshell waste produced every day is 312 grams. Eggshells consist of $97 \%$ calcium carbonate (Hunton 2005). Organic waste such as eggshells contribute to environmental pollution that need disposal costs and availability of places (Gaonkar and Chakraborty 2016). In addition, the smell of eggshells invite flies. Processing eggshells into fertilizers can cut the amount of waste thrown into the environment. Even though it is small, improper handling is very harmful.

Eggshell fertilizer can increase $\mathrm{pH}$ and calcium content in the soil (Gaonkar and Chakraborty 2016). Mashfufah (2014) found that organic fertilizers from eggshell have a good influence on the growth of celery, and increase the growth of soybean plants by $36.11 \%$ and the yield of plants by $35.45 \%$ on dry land (Mariani 2017). This fertilizer can also be used in conjunction with chicken manure. The results of the Sevindrajuta (2017) study, chicken manure with the addition of eggshell fertilizer gives the highest melon fruit growth compared to other manure.

3.3.4. Processing of Slices and Rejected Flat Bread to Bread Crumb Flour

The process of slicing fresh bread produces pieces and bread crumbs. The bread loaf is immediately discarded without being processed first. It is necessary to add a container to accommodate the remnants of the slices to be used again. Fresh bread that does not pass the selection is also immediately discarded. The number of breads that do not pass the selection every day is about 20 packs (the average weight of each pack of bread that does not pass the selection is 250 grams so that the total is 5,000 g/day) while the remaining bread is 919.69 grams per day. The total weight produced in both processes are $5919.69 \mathrm{~g} /$ day. These wastes can be processed into bread crumb flour from bread by heating it to the oven and then reducing its size using a food processor (Suryana 2013).

3.3.5. Gradual Washing

The washing process of the batter and rack is usually done once a week on Saturday. Washing is done using running water. The number of pan and rack used is around 200 pieces. This causes a large amount of water used. Indrasti and Fauzi (2009) said that washing the pan can be done in four stages, namely immersion, sapling, rinsing 1 , and rinsing 2 . Washing with a gradual system can cut the amount of water use compared to the use of running water.

3.3.6. Submission of Halal Certification

One of the factors that led to high unsold products was the absence of halal certification. Syahputra and Hamoraon (2013) found that around $75 \%$ of consumers pay attention to halal certification as a consideration in buying products. In addition, awareness of the Muslim community about halal food is increasing. Submission of halal certificates is expected to increase sales to retail.

3.3.7. Processing of Unsold Bread into Animal Feed

The percentage of products that are not sold every month for the type of flat bread is $15 \%$ while for sweet bread is $40 \%$. The high number of unsold products made the industry have to think about efforts that can be made to treat the waste. Initially the Multy Bakery teamed up with fish farm, but along with the catastrophic floods that happened to the farmers causing bread waste to accumulate to tens of sacks. The selling price of bread waste to farm farmers was Rp 1,000/kg.

Bread waste has $4.217 \mathrm{Kcal} / \mathrm{kg}$ gross energy, 10.25\% crude protein, and 13.42\% fat (Hidayatullah 2017), $12.04 \%$ crude fiber, $0.07 \%$ calcium, $0.019 \%$ phosphorus, $6.91 \%$ water and $0.80 \%$ ash (Gaol et al. 2015). The use of bread waste as a substitute for corn in animal feed to $60 \%$ produces the same and optimal results (Hidayatullah 2017). Processing yields in the process of tipping using disk mill amounted to 91.61\% (Rangkuti et al. 2012). The selling price of bread waste flour was around $\mathrm{Rp} 1,500-2,000 / \mathrm{kg}$. This price certainly has a 
greater value when compared to the sale of bread waste in its original form.

\subsection{Feasibility Analysis of Cleaner Production Alternatives}

Feasibility analysis used of the alternative of cleaner production includes technical, environmental, and financial feasibilities. Technical feasibility is seen from implementation possibility while environmental feasibility is the waste produced reduction (Khuriyati et al. 2015). Financial feasibility is seen by calculating the pay back period for each cleaner production alternative (Table 6).

The performance of Multy Bakery will experience some changes along with the implementation of the cleaner production. There will be an increase in the raw material for making the dough because of minimization of the dough loss. Washing water waste will decrease due to gradual washing. Bread returns which are initially processed by means of being sold to catfish farmers will be processed into animal feed raw materials in the feed industry. Processed solid waste will increase compared to the previous one which was only thrown away. Eggshells will be processed into fertilizer, and slices of flat bread and sweet bread that do not pass the selection become bread crumb flour. Sales will increase with halal certification (Table 7).

Every alternative to cleaner production has a financial advantage. The biggest financial benefit value was Rp. 15,730,000 from implementation of GMP, while the smallest was Rp. 29,076 from daylight lighting (Table $8)$.

Table 4. Feasibility of cleaner production alternative

\begin{tabular}{|c|c|c|c|c|c|}
\hline \multirow{2}{*}{ Aspect } & \multirow{2}{*}{ Problems } & \multirow{2}{*}{ Altemative } & \multicolumn{3}{|c|}{ Feasibility } \\
\hline & & & Technical & Environment & Financial \\
\hline $\begin{array}{l}\text { Production } \\
\text { process }\end{array}$ & $\begin{array}{l}\text { - Do not have a special } \\
\text { fermentation room. } \\
\text { - There is no } \\
\text { determination of } \\
\text { fermentation time, } \\
\text { temperature and RH. }\end{array}$ & $\begin{array}{l}\text {-Construct } \\
\text { special } \\
\text { fermentation } \\
\text { rooms. } \\
\text { - Buy } \\
\text { temperature and } \\
\text { RH controller } \\
\text {-Determination } \\
\text { of } 60 \text { minutes } \\
\text { fermentation } \\
\text { time }\end{array}$ & $\begin{array}{l}\text { - Construct } \\
\text { new facilities } \\
\text { - Cut } \\
\text { fermentation } \\
\text { time }\end{array}$ & $\begin{array}{l}\text { Prevention of } \\
\text { microbiological } \\
\text { contamination in the } \\
\text { dough and reduction of } \\
\text { the product fails } \\
\text { because the process } \\
\text { conditions are not } \\
\text { optimum }\end{array}$ & $\begin{array}{l}\text {-Investment: } R p 20,035,000 \\
\text {-Profit: } R p \text { 3,218,000 } \\
\text {-Pay back period 6,23 months }\end{array}$ \\
\hline \multirow[t]{2}{*}{$\begin{array}{l}\text { Manage- } \\
\text { ment }\end{array}$} & $\begin{array}{l}\text { - Wheat flour scattered } \\
\text { on the floor } \\
\text { - Smoking in the } \\
\text { production room } \\
\text { - Put things off place } \\
\text { - Dough spills from the } \\
\text { pan }\end{array}$ & $\begin{array}{l}\text { Good } \\
\text { Manufacturing } \\
\text { Practices } \\
\text { (GMP) }\end{array}$ & $\begin{array}{l}\text { GMP training } \\
\text { for one } \\
\text { person in } \\
\text { charge of } \\
\text { production }\end{array}$ & $\begin{array}{l}\text { - Reducing the amount } \\
\text { of spilled flour } \\
\text { - The floor is not } \\
\text { slippery } \\
\text { - Reduction of } \\
\text { accidents to workers }\end{array}$ & $\begin{array}{l}\text {-Investment: Rp } 4,550,000 \\
\text {-Additional income: } \\
\text { Rp } 15,730,000 \\
\text {-Pay back period } 0.29 \text { month }\end{array}$ \\
\hline & $\begin{array}{l}\text { Use of lights during the } \\
\text { day }\end{array}$ & $\begin{array}{l}\text { Lighting energy } \\
\text { savings during } \\
\text { the day }\end{array}$ & $\begin{array}{l}\text { Installation of } \\
\text { solartuff } \\
\text { transparent } \\
\text { tiles }\end{array}$ & $\begin{array}{l}\text { Energy reduction of } \\
0.792 \mathrm{kWH} / \text { day }\end{array}$ & $\begin{array}{l}\text {-Investment: Rp. } 576,000 \\
\text {-Profit: Rp } 29,075 \\
\text {-Pay back period } 19.81 \text { months }\end{array}$ \\
\hline \multirow{3}{*}{ Wastes } & $\begin{array}{l}\text { - Egg shells are } \\
\text { immediately thrown into } \\
\text { the environment causing } \\
\text { odor }\end{array}$ & $\begin{array}{l}\text { Organic } \\
\text { fertilizer }\end{array}$ & $\begin{array}{l}\text { Easy to do, } \\
\text { just once a } \\
\text { month }\end{array}$ & $\begin{array}{l}\text { Reduction of } \mathrm{CaCO}_{3} \\
\text { pollution in eggshells }\end{array}$ & $\begin{array}{l}\text {-Investment: } \mathrm{Rp} 920,400 \\
\text {-Profit: } \mathrm{Rp} 79,150 \\
\text {-Payback period } 3.97 \text { month }\end{array}$ \\
\hline & $\begin{array}{l}\text { The remaining slices and } \\
\text { rejected breads are } \\
\text { immediately discarded }\end{array}$ & Crumb flour & $\begin{array}{l}\text { Buy food } \\
\text { processor }\end{array}$ & $\begin{array}{l}\text { Reduction in the } \\
\text { amount of waste up to } \\
133.45 \mathrm{~kg} / \text { month }\end{array}$ & $\begin{array}{l}\text {-Investment: Rp } 67,000 \\
\text {-Profit: Rp } 394,550 \\
\text {-Payback period } 1.7 \text { moths }\end{array}$ \\
\hline & $\begin{array}{l}\text { Washing in running } \\
\text { water }\end{array}$ & $\begin{array}{l}\text { Four stages } \\
\text { washing }\end{array}$ & $\begin{array}{l}\text { Need a } \\
\text { special place } \\
\text { and tub } \\
\text { making } \\
\text { services }\end{array}$ & $\begin{array}{l}\text { The use of water is } \\
\text { reduced by } 400 \text { liters / } \\
\text { month }\end{array}$ & $\begin{array}{l}\text {-Investment: } \mathrm{Rp} 624,050 \\
\text {-Profit: Rp } 128,452 \\
\text {-Payback period } 4.86 \text { month }\end{array}$ \\
\hline \multirow{2}{*}{ Product } & $\begin{array}{l}\text { Bread is only sold in } \\
\text { stores not in } \\
\text { supermarkets (no halal } \\
\text { certificate) }\end{array}$ & $\begin{array}{l}\text { Submission of } \\
\text { halal } \\
\text { certification }\end{array}$ & $\begin{array}{l}\text { Submit to } \\
\text { MUI } \\
\text { (Moslem } \\
\text { Council of } \\
\text { Indonesia) }\end{array}$ & $\begin{array}{l}\text { - Increased product } \\
\text { sales so that unsold } \\
\text { products are reduced }\end{array}$ & $\begin{array}{l}\text {-Investment: } \operatorname{Rp} 2,500,000 \\
\text {-Profit: Rp } 951,467 \\
\text {-Paybackperiod } 2.63 \text { months }\end{array}$ \\
\hline & Unsold breads & $\begin{array}{l}\text { Animal feed } \\
\text { flour }\end{array}$ & Use disk mill & $\begin{array}{l}\text { - Reduction in the } \\
\text { amount of bread waste } \\
\text { - Increase the sale } \\
\text { value of waste }\end{array}$ & $\begin{array}{l}\text {-Investment: } \mathrm{Rp} 8,754,000 \\
\text {-Profit: Rp } 793,701 \\
\text {-Payback period } 11.03 \text { months }\end{array}$ \\
\hline
\end{tabular}


Table 5. Performance before and after implementation of cleaner production

\begin{tabular}{|c|c|c|}
\hline \multirow{2}{*}{ Specific Parameters } & \multicolumn{2}{|c|}{ Performance/month } \\
\hline & Before & After \\
\hline Bread Production (ton) & 21.19 & 21.80 \\
\hline Washing water (liter) & 4,000 & 3,600 \\
\hline Electrical Energy for Production (kWh) & 1613.27 & 1592.68 \\
\hline Processed solid waste (ton) & 3.27 & 3.43 ton \\
\hline Flat Bread (packs) & 33,384 & 34,996 \\
\hline Sweet Bread (packs) & 13,962 & 14,560 \\
\hline
\end{tabular}

Table 6. Financial benefits for every cleaner production alternative

\begin{tabular}{|l|r|}
\hline Alternative & Benefit (Rp/month) \\
\hline Making special fermentation space and determining fermentation time & $3,217,830$ \\
\hline Good Manufacturing Practice & $15,730,00$ \\
\hline Lighting during the day & 29,076 \\
\hline Organic fertilizer & 79,134 \\
\hline Crumb flour & 394,533 \\
\hline Staging Wash & 128,452 \\
\hline Submission of halal certificate & 951,467 \\
\hline Animal feed raw materials & 793,701 \\
\hline Total & $21,324,193$ \\
\hline
\end{tabular}

\section{Conclusions and Recommendations}

\subsection{Conclusions}

Sources of waste and inefficiencies that occur were in the production process, management, waste and product aspects. The research found various problems: (i) no special fermentation chambers and no fermentation timing, (ii) scattered flour, (iii) smoking workers, (iv) spilled dough, (v) put things out of place, (vi) use of lights during the day, (vii) eggshells were thrown away, (viii) bread slices and rejected breads were discarded, (ix) liquid waste was disposed in running water, $(\mathrm{x})$ unsold bread, and (xi) do not have a halal certificate.

Recommend cleaner production alternatives are (i) making special fermentation chamber, (ii) determination of fermentation time, (iii) Good Manufacturing Practice, (iv) lighting design during the day, (v) eggshell processed into fertilizer, (vi) remaining sliced and rejected breads are processed into bread crumb flour, (vii) four stages washing, (viii) submitting halal certificates, and (ix) bread waste flour as animal feeds.

The implementation of cleaner production will cut water and energy used. GMP has the fastest payback period of 0.29 months, while lighting design during the day has the longest payback period of 19.81 months. The bread production will be increasing from 21.19 to 21.80 ton/month, washing water decreasing from 4,000 to 3,600 liter/month, electricity decreasing from 1613.27 to $1592.68 \mathrm{kWh} / \mathrm{month}$, processed solid waste will increase from 3.27 to 3.43 ton/month, and increasing sales of flat bread to 34,996 packs/month and sweet bread $14,560 \mathrm{packs} / \mathrm{month}$. The total profit obtained after the implementation of the cleaner production per month will be Rp. 21,324,193.

\subsection{Recommendations}

Small bread industries should have special staff to handle the environmental aspects to cut the waste produced and to apply cleaner production in real terms. There is a need for further research to carry out recommended cleaner production alternatives to see the real effect on small bread industries.

\section{References}

Abou-Elela SI, Nasr FA, El-Shafai SA. 2008. Watewater management in small and medium size enterproses: case studies. Environmenta List 28: 289-296.

Abou-Elela. 2002. Cleaner production in Egyptian edible oil and soap industry. Proceeding of International Symposium and Workshop on Environmental Pollution Control and Waste Management. 7-10 January 2002.

Aguilar CMG, Panameno R, Velazquez AP, Alvarez BEA, Kiperstok A, Cesar SF. 2017. Cleaner production applied in a small furniture industry in Brazil: addressing focused changes in design to reduce waste. Sustainability 9.

Aminah S, Meikawati W. 2016. Calcium content and flour yield of poultry eggshell with acetic acid extraction. The $4{ }^{\text {th }}$ Unversity Research Coloquium.

Anggraini T, Yudhastuti R. 2014. Penerapan good manufacturing practice pada industri rumah tangga kerupuk 
teripang di Sukolilo Surabaya. Jurnal Kesehatan Lingkugan 7(2), 148-158.

Bajd F, Sersa I. 2011. Continuous monitoring of dough fermentation and bread baking by magnetic resonance microscopy. Magnetic Resonance Imaging 29, 434-442.

Berkel RV. 1999. Cleaner production opportunities for small to medium sized enterprises. Waste and Recycle Convention 5-6 Agustus 1999.

Dan NP, Visvanathan C, Kumar S. 2003. Cleaner production potentials in seafood processing industry: a case study from Ho Chi Minh City Vietnam. National University of Ho chin Minh Vietnam.

Fore S, Mbohwa CT. 2010. Cleaner production for environmental conscious manufacturing in the foundry industry. Journal of Engineering Design and Technology 8(3), 314-333.

Gaol SEL, Silitonga L, Yuanita I. 2015. Substitusi ransum jadi dengan roti afkir terhadap performa burung puyuh (Coturnix coturnix japonica) umur starter sampai awal bertelur. Jurnal Ilmu Hewani Tropika 4(2), 61-65.

Gaonkar M, Chakraborty AP. 2016. Application of eggshell as fertilizer and calcium supplement tablet. International Journal of Innovative Research in Science Engeneering and Technology 5(3), 3520-3525.

Hafiz MIM, Zulfattah ZM. Munajat NA, Sakinah ABF, Asyraf H. Cleaner production implementation at chicken slaughtering plant. International Journal of Applied Environmental Sciences 11(2), 515-523.

Hens L, Block C, Cabello-Eras JJ, Sagastume-Gutierez A, Grcia-Lorenzo D, Chamoro C, Mendoza H, Haeseldonckx D, Vandecasteele C. 2017. On the evolution of cleaner production as a concept and a practice. Journal of Cleaner Production. DOI:10.1016/j.jclepro.2017.11.082

Hidayatullah MF, Djunaidi IH, Natsir H. 2014. Efek penggunaan tepung limbah roti tawar sebagai pengganti jagung terhadap penampilan produksi itik hibrida. Jurnal Fakultas Peternakan Universitas Brawijaya Edisi 2 Volume 1.

Hunton P. 2005. Research on eggshell structure and quality: an historical overview. Brazilian Journal of Poulty Science 7(2), 67-71.

Indrasti NS, Fauzi A. 2009. Produksi Bersih. Bogor (ID): IPB Press. Bogor, Indonesia.

JICA. 2002. The Study on Promotion of Cleaner Production in Industrial Sector. Mitsubishi Chemical Engineerong Corporation.

Khuriyati N, Wagiman, Kumalasari D. 2015. Cleaner production for improving environmental performance of small scale cracker industry. Agriculture and Agricultural Science Procedia 3, 102-107.

Koswara S. 2009. Teknologi Pengolahan Roti. eBookPangan.com http://tekpan.unimus.ac.id.

Mariani. 2017. Uji dosis teoung cangkang telur untuk meningkatkan pertumbuhan dan hasil kedelai di lahan kering. Jurnal SAINTA 1(2), 60-106.

Mashfufah NH. 2014. Uji potensi pupuk organik dari bahan cangkang telur untuk pertumbuhan tanaman seledri (Apium graveolens L.) [skripsi]. Surakarta (ID): Universitas Muhammadiyah Surakarta.

Mudjajanto ES dan Yulianti LN. 2004. Membuat Aneka Roti. Jakarta (ID): Penebar Swadaya.

Nugroho WA, Sucipto, Saparianti E. 2015. Introduksi cara-cara pengolahan pangan yang baik dan peralatan mekanis untuk perbaikan proses produksi UKM Rotterdam Bakery. Journal of Innovation and Applied Technology 1(2), 124-130.

Rahim R, Raman AAA. 2015. Clenaer production implementation in a fruit juice production plant. Journal of Cleaner Production 101, 215-221.

Rahman MS, Datta S, Islam S. 2014. Waste generation and management practices in BSCIC Mymensingh. Jurnal Environmental Science and Natural Resources 7(1), 47-51.

Rahmawati WA, Nisa FC. 2015. Fortifikasi kalsium cangkang telur pada pembuatan cookies (kajian konsentrasi tepung cangkang telur dan baking powder). Jurnal Pangan dan Agroindustri 3 (3), 1050-1061.

Ramjeawon T. 2004. A case study of cleaner production opportunities in small and medium enterprises on the Islan of Mauritius. Electronic Green Journal 1 (20).

https://escholarship.org/uc/item/1rd948gh

Rangkuti PA, Hasbullah R, Sumariana KSU. Uji performansi mesin penepung tipe disk (disk mill) untuk penepungan juwawut. Agritech 32(1), 66-72.

Rocha FBDA, Oliveira LFAD, Campos MC, Oliveira LPD, Saldanha MCWS. 2009. Analysis of ergonomic demands in the bread making section of a bakery in Natal? RN: a case study. XIV International Conference on Industrial Engineering and Operations Management 06-09 October Brazil.

Rodriguez AG. 2017. Energy audit of a bakery in Sweden [Thesis]. Sweden (SE): University of Galve.

Sevindrajuna. 2017. Respon pertumbuhan dan hasil tanaman melon (Cucumis melo, L.) akibat pemberian tepung cangkang telur dengan berbagai jenis pupuk kandang. Jurnal Pertanian UMSB 1(2), 22-28.

Shamsudin, Rahman RA, Saad NM, Baharum N, Baharom N, Mawi MR, Raman AAA, Rahim R, Shah RSSRE. 2011. Cleaner Production Tips for Small and Medium Industries. Putrajaya (MY): Department of Environment Malaysia Ministry of Natural Resources \& Environment Malaysia.

Sulistyaningrum A, Rahmawati, Aqil M. 2017. Karakteristik tepung jawawut varietas lokal Majene dengan 
perlakuan perendaman. Jurnal Penelitian Pascapanen Pertanian 14(1), 11-21.

Suryana D. 2013. Membuat Tepung : Resep Mambuat Tepung. Yogyakarta (ID): Penerbit Kanisius.

Suryatna BS. 2015. Peningkatan kelembutan tekstur roti melalui fortifikasi rumput laut Euchem Cottoni. Teknobuga 2(2), 18-25.

Syahputra A, Hamoraon HD. 2013. Pengaruh labelisasi halal terhadap keputusan masyarakat Kecamatan Perbaungan dalam pembelian produk makanan dalam kemasan. Jurnal Ekonomi dan Keuangan 2(8), 475487.

Syam ZZ, Kasim A, Nurdin M. 2014. Pengaruh serbuk cangkang telur ayam terhadap tinggi tanaman kamboja jepang (Adenium obesum). e-Jipbiol 3, 9-15.

Tan M, Ayhan E, Baydas M. 2016. Sustainability and cleaner production; case textile and clothing sectors in Bingol. Journal of Macro Trends in Energi and Sustainability 1(4), 22-33.

TERI. 2016. Cluster Profile Coimbatore Bakery Industries. New Delhi (IN): TERI Press.

Tisnowati H, Hubeis M, Hardjomidjojo. 2008. Analisis Pengendalian Mutu Produksi Roti (Kasus PT AC Tangerang). Jurnal MPI 3(1), 51-61.

UNEP. 1990. Resource Efficient and Cleaner Production [internet] [diakses pada 2018 Mei 28] www.unep.fr/scp/cp/.

UNIDO. 2009. Funding Options for Small and Medium Size Enterprises to Finance Cleaner Production Projects and Environmentally Sound Technology Investment. Vienna (AT): United Nation Industrial Development Organization.

Visvanathan C, Kumar S. 1999. Issues for better implementation of cleaner production in Asian small and medium industries. Journal of Cleaner Production 7, 127-134.

Vos CD, Simonsesn M, Oort MV, Autton S, Alanen A, Caelenberg TV. 2018. Industry guidlines on the safe handling of enzymes in the bakery supply chain. AMFEP (Association of Manufactures and Formulators of Enzyme Products).

Yi H, Kim J, Hyung H, Lee S, Lee CH. 2001. Cleaner production option in a food (Kimchi) industry. Journal of Cleaner Production 9, 35-41. 